\title{
TRADITIONAL RURAL WETLANDS IN HARYANA STATE OF INDIA ARE CURRENTLY CONFRONTING MULTICORNERED THREATS LEADING TO EXTINCTION SOONER THAN LATER
}

\author{
ROHTASH CHAND GUPTA ${ }^{1}$ AND TIRSHEM KUMAR KAUSHIK ${ }^{*}$
}

${ }^{1}$ Department of Zoology, Kurukshetra University

\begin{abstract}
The most serious threat to traditional rural ponds in Haryana is associated with transformed societal behavioural patterns, ethics, values and life style, amongst several others. The siltation of ponds with adjoining areas, soil coming in with rain water is a very serious cause of stratification of rural ponds. Also contracting of village community land for sun drying of cow dung cakes inspires villagers to overload periphery of each pond with cow dung turning the premises into grave-yard of dung. This dung is the major source of polluting pond water into blackish water with high load of organic matter. Moreover, it leads to over excessive eutrophication. Building of major highways and connectivity roads have resulted into compartmentalization and degradation of village ponds. Inhabitation of peripheral village ponds boundaries by lower section of society for dwelling purposes is more threat to wetlands. The indifferent inclination of villagers towards silted ponds drenched in bad odour and blackish sludge is the story of $80 \%$ of the cases. The total blockage of run-off rainy water towards the natural age old rural ponds due to obstruction by way of human inhabitation has resulted into desertification of shallow water sheet in $90 \%$ of the cases. The oblivion of harvesting dried silt in summer for brick making has spelled doom for the ponds turning them into flat ground through successive decades and so on. The water quality in all ponds was overshooting the decaying stage due to the continuous mixing of cow dung drenched rainy water. Over excessive usage of ponds for bathing of cattle, dumping of cow dung and rotten vegetables waste has turned ponds into live sinks of dirt, garbage and rural dairy wastes. Majority of village ponds are now out of existence or in deep black sludge laden or converted into Fish-Farming wetlands. The present studies have indicated that Winter migratory birds like Greylag Goose Anser anser, Bar-headed Goose Anser indicus, Mallard Anas platyrbynchos, Gadwall Anas strepera, Northern Shoveller Anas clypeata, Northern Pintail Anas acuta, Garganey Anas querquedula, Common Teal Anas crecca, Common Pochard Aythya ferina, Tufted Pochard Aythya fuligula, Common Coot Fulica atra, Little Ringed Plover Charadrius dubius, Kentish Plover Charadrius alexandrines, Spotted Redshank Tringa erythropus, Common Redshank Tringa tetanus, Marsh Sandpiper Tringa stagnatilis, Wood Sandpiper Tringa glareola and Pied Avocet Recurivirostra avosetta arrive in the extremely dilapidated rural ponds in Haryana from far off places including Russia, Siberia, China, and Caspian region, east Asia each winter season without any break. As such the extinction of ponds in Haryana directly threatens global avian biodiversity.
\end{abstract}

Keywords: Traditional Rural Wetlands, Perennial Rainy Water, Road Side Puddles, Land Filling, Commercial and Residential Construction, Highway reconstruction

\section{INTRODUCTION}

Haryana state in India stands for agriculture revolution and widespread economic growth linked with govt. policies, peoples' sense of awareness, outsourcing of youth to abroad and

*Corresponding address:

Tirshem Kumar Kaushik

Depertment of Zoology, Kurukshetra University, kurukshetra, Haryana

India 136119

Email : tarshemkaushik@rediffmail.com availability of world class professional colleges in the private sector. Traditional villagers are in the midst of profound social transformation in correlation with extensive and intensive generation of infrastructure of various hues. These developments have also resulted in destructing of erstwhile balanced façade of environmental components. One visible effect is negatively influencing the age old rural wetlands. Each village, in the earlier times and as recently as 30-40 years back used to have 4-5 self maintained ponds. These ponds were the best 
natural depressions to receive run-off rainy water in a self driven style. These ponds were the water sheets for the rural society of India since times immemorial. During lean period of availability of water (November to June), these ponds served as ready resource of water. Herds of cattle would drink and bath in these ponds. Tortoises, Pond herons, Cattle Egrets, Cormorants, Pelecypods, Gastropods, wide range of diatoms and vegetation will thrive in these ponds. During the summer season, the villagers used to excavate the silt for purposes like brick making and strengthening of Kuchha roof tops to secure against water leakage in rainy season was one self driven practice ensuring the proper maintenance of depth parameter thus leading to the perpetual existence of rural ponds - is now totally wanting. The present studies are actually a fall off of our endeavour to make an account of migratory birds in Haryana [1-16] During these surveys, we witnessed the holocaust being poured on village ponds in Haryana and hence the present study.

\section{MATERIALS AND METHODS}

The present studies are restricted to Haryana state $\left(30^{\circ} 44^{\prime} \mathrm{N} 76^{0} 47^{\prime} \mathrm{E} / 30.73^{\circ} \mathrm{N} 76.78^{\circ} \mathrm{E}\right)$ in India having an approximate area of $44,212 \mathrm{~km}^{2}(17,070.3 \mathrm{sq} \mathrm{mi})$ with $25,353,081$ human population. Extensive survey was done by traveling National Highways (No.1, 73, 08) and state highways between Kurukshetra Rohtak - Charkhi Dadri - Loharu; (ii)Kurukshetra - Ladwa - Yamunanagar - Ponta Sahib; (iii)Kurukshetra -Kaithal - Narwana Hisar; (iv) Delhi -Faridabad - Ballabgarh Palwal - Hodal -Mathura. In addition extensive survey was done in Thanesar, Pehowa and Ladwa blocks of Kurukshetra district. Similarly Nilokheri, Karnal, Nissing, Assand, Indri, Gharaunda blocks of Karnal district were surveyed extensively.

The entire state of Haryana was surveyed under one or the other pretext at random specially focusing attention on the studies of migratory wetland birds since 1985 onwards. Also various ponds across Haryana were visited to find out the status of tortoises in Haryana w.e.f. 2005 onwards. The state of Haryana was traversed on roads at random while undertaking several official obligations. During all these forays, ponds in villages were not only glanced at but were surveyed in entirety. The observations are casual, yet capable of addressing on issue in its entirely, as if hitting a nail on its head. The photographs have been taken with the help of
Camera Zenith 1986Model with Russian Made tele-lens. Above all, in totality the visits to the field are spread over two decades and on several occasions in a year without maintain strict mannerism or periodicity.

In order to generate information on ambient conditions prevailing in rural village ponds, a very simple "questionnaire" was designed. In all 555 questionnaires were filled in respect of each and every village pond spread over seven districts. It is relevant to mention here that in each block 15 village ponds were selected for study. The some of the point of questionnaire were filled up self and others were filled by interviewing the villagers.

\section{RESULTS AND DISCUSSION}

It is evident from table-1 that wide variety of ponds across districts, blocks, tehsils were visited across Haryana specially between 2005 to 2011 for recording migratory birds and studying threats to ponds point of view. This study also indicate that majority of village ponds in Haryana are littered with threats to their very existence and are now converted into degraded sludge tanks, eutrophied water sheets, flats and cow dung cakes in thousands and lakhs (Figure 1). It is evident from this table 1 that not even a single pond was found with clean blue litting waters. It is pertinent to mention that out of 550 village ponds, 450 rural ponds have been used for Fish and Fisheries. According to one estimate, there are in all 8065 ponds in Haryana out of which $90 \%$ are fish ponds producing 1,00,000 MT of fish worth crores of rupees. A net profit of 61000 per hectare per year is obtained. There are 8065 fish culture units having an area of more than 12883 hectares in the state.

As such, it is borne out of the prevailing scenario that fish farming practices pause a greater danger to traditional ponds and their erstwhile rich floral and faunal biodiversity. It is evident from table-1 that principal threats to the very existence of village ponds in Haryana are fish farming, practice of sun-drying of cow dung by villagers, encroachment of ponds for house building purposes, encroachment on ponds premises by land filling for unlawful expansion of private agriculture land lastly but not the least encroachment of village ponds by Govt. sponsored projects for construction of modern highway [Panipat-Jalandhar GT Road expansion Project (2010-2012A.D). 
Gupta et al. [2] reported 63 species of wetland birds from Kaithal district in Haryana. At the same time, Gupta and Kaushik [5] recorded 66 species of Wetland birds from Kurukshetra district. Similarly, Gupta and Kaushik [7] observed 58 species of wetland birds from Yamunanagar district in Haryana (India).It is pertinent to mention that, all these birds which are coming from across the Himalayas are facing adverse conditions in their winter sojourn in rural ponds in northern Haryana.

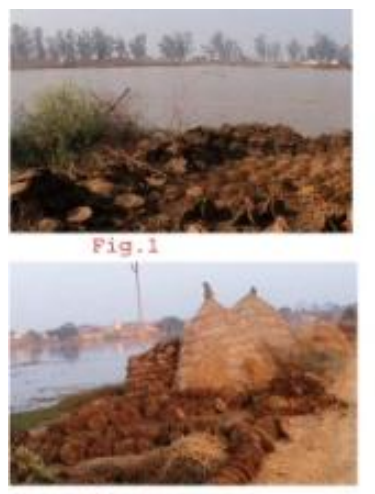

Fig. 3
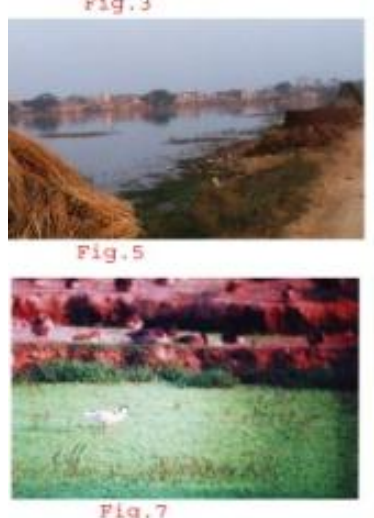

Fig. 7
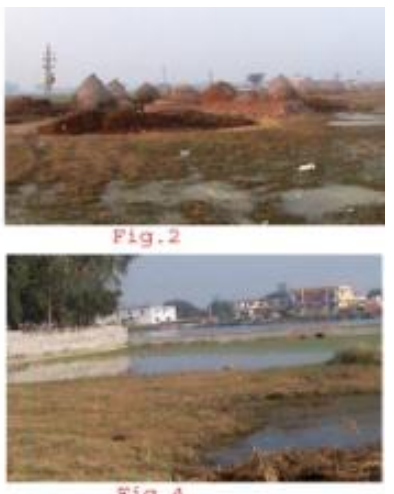

Fig. 4
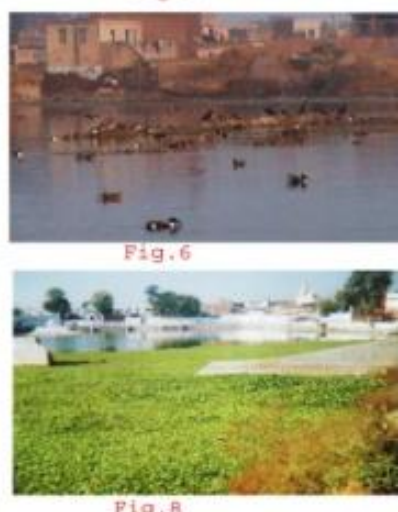

Pig. B
Figure 1. Pictorial representation of scenario prevailing in rural ponds in Haryana

Winter migratory birds like Greylag Goose Anser anser, Mallard Anas platyrbynchos, Gadwall Anas strepera, Northern Shoveller Anas clypeata, Northern Pintail Anas acuta, Garganey Anas querquedula, Common Teal Anas crecca, Common Coot Fulica atra, Little Ringed Plover Charadrius dubius, Kentish Plover Charadrius alexandrines, Spotted Redshank Tringa erythropus, Common Redshank Tringa tetanus, Marsh Sandpiper Tringa stagnatilis, Wood Sandpiper Tringa glareola and Pied Avocet Recurivirostra avosetta are commonly seen in rural ponds in Haryana during winter season each year. At the same time, birds like Painted Stork Mycteria leucocephala, White-necked Stork Ciconia episcopus, Common Pochard Aythya ferina, Tufted Pochard Aythya fuligula, Spotted Greenshank Tringa guttifer, Comb Duck

Sarkidiornis melanotos, Black Ibis Pseudibis papillosa, Oriental White Ibis Threskiornis melanocephalus, Bar-headed Goose Anser indicus, and Eurasian Spoonbill Platalea lencorodia (Figure 2) are also observed from rural ponds in Haryana. These wetland birds are confronting with adverse conditions in these traditional rural ponds in Haryana.

The construction of national Highway No. 1 has dealt a severe blow to few very healthy ageold ponds across its $260 \mathrm{KMs}$ length between Panipat and Jalandhar between 2009-11. Also the expansion of this very highway in its first phase (2004-08) between Delhi and Panipat has already wiped out several rural ponds. It is pertinent to mention that observations between 1984 to 2011

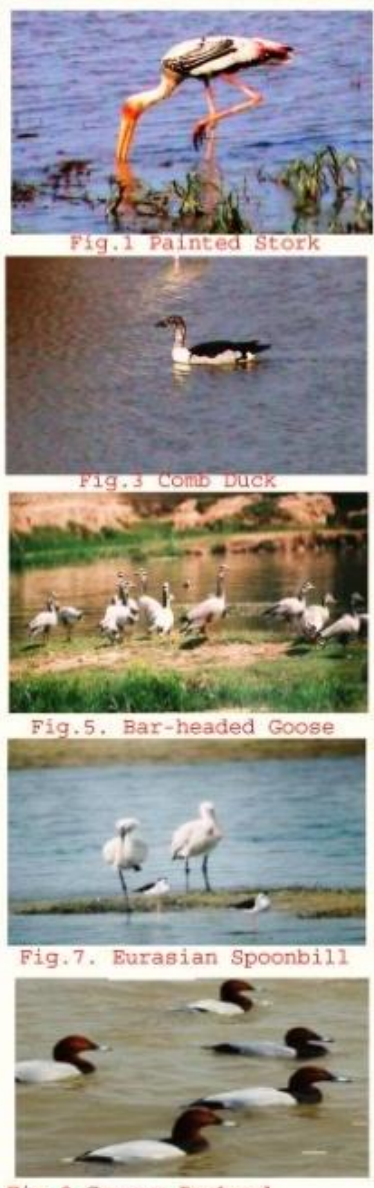

Fig.9. Common Pochard

Figure 2. Photographic inventory of wetland birds observed at rural ponds in Haryana

repause belief into the fact that GT ROAD between Delhi and Amritsar has time honoured crystal clear water bodies all across its length both sides with rich diversity of flora and fauna including wide array of plants and animal life. Today, in the first place, these discontinuous perennial shallow water bodies' stands eliminated. In the second place, the left over bodies are devoid of life whatsoever. 
Table 1. The overall scenario prevalent in rural ponds in northern Haryana in context of winter migratory wetland birds during 2005-11

\begin{tabular}{|c|c|c|c|c|}
\hline S1. NO. & $\begin{array}{l}\text { ASPECTS OF } \\
\text { VILLAGE PONDS }\end{array}$ & OBSERVATIONS & $\begin{array}{l}\text { TOTAL NO. OF } \\
\text { PONDS }\end{array}$ & PERCENTAGE \\
\hline \multirow[t]{3}{*}{1} & \multirow[t]{3}{*}{ Size of the Pond } & 1-3 Acres & 115 & $20.72 \%$ \\
\hline & & 4-7 Acres & 330 & $59.45 \%$ \\
\hline & & 8-10 Acres & 110 & $20 \%$ \\
\hline \multirow[t]{2}{*}{2} & \multirow{2}{*}{$\begin{array}{l}\text { Distance of pond from } \\
\text { the main Human } \\
\text { dwelling }\end{array}$} & Within the outskirts & 420 & $75.67 \%$ \\
\hline & & Outside the village & 135 & $24.32 \%$ \\
\hline \multirow[t]{2}{*}{3} & \multirow[t]{2}{*}{ Perennial/seasonal } & Perennial & 555 & $100 \%$ \\
\hline & & seasonal & 0 & $0 \%$ \\
\hline \multirow[t]{3}{*}{4} & \multirow[t]{3}{*}{ Character of moorings } & Regular & 80 & $14.41 \%$ \\
\hline & & Irregular & 400 & $72.07 \%$ \\
\hline & & Cemented & 75 & $13.51 \%$ \\
\hline \multirow[t]{3}{*}{5} & \multirow[t]{3}{*}{ Depth of Moorings } & 3-4 ft. & 415 & $74.77 \%$ \\
\hline & & $5-6 \mathrm{ft}$. & 80 & $14.41 \%$ \\
\hline & & $7-8 \mathrm{ft}$. & 60 & $10.81 \%$ \\
\hline \multirow[t]{2}{*}{6} & \multirow[t]{2}{*}{ Bathing by Humans } & Yes & 40 & $7.20 \%$ \\
\hline & & No & 515 & $92.79 \%$ \\
\hline \multirow[t]{2}{*}{7} & \multirow{2}{*}{ Cattle bathing } & Yes & 530 & $95.49 \%$ \\
\hline & & No & 25 & $4.50 \%$ \\
\hline \multirow[t]{2}{*}{8} & \multirow[t]{2}{*}{ Fish and Fisheries } & Yes & 450 & $80.08 \%$ \\
\hline & & No & 105 & 18.91 \\
\hline \multirow[t]{2}{*}{9} & \multirow[t]{2}{*}{ Laundry } & Yes & 25 & $4.50 \%$ \\
\hline & & No & 530 & $95.49 \%$ \\
\hline \multirow[t]{3}{*}{10} & \multirow{3}{*}{$\begin{array}{l}\text { Cattle dung cakes } \\
\text { preparation }\end{array}$} & Intense & 450 & $80.08 \%$ \\
\hline & & Mediocre & 55 & $10 \%$ \\
\hline & & nominal & 50 & $9.009 \%$ \\
\hline \multirow[t]{3}{*}{11} & \multirow{3}{*}{$\begin{array}{l}\text { Dumping of village } \\
\text { garbage }\end{array}$} & Intense & 400 & $72.07 \%$ \\
\hline & & Mediocre & 85 & $15.31 \%$ \\
\hline & & nominal & 70 & $12.61 \%$ \\
\hline \multirow[t]{2}{*}{12} & \multirow[t]{2}{*}{ Rain water reception } & Yes & 555 & $100 \%$ \\
\hline & & No & 0 & $0 \%$ \\
\hline \multirow[t]{2}{*}{13} & \multirow{2}{*}{$\begin{array}{l}\text { Overall condition of } \\
\text { maintenance }\end{array}$} & Nominal & 55 & $10 \%$ \\
\hline & & Zero & 500 & $90 \%$ \\
\hline \multirow[t]{3}{*}{14} & Disturbance due to & Intense & 420 & $75.67 \%$ \\
\hline & human activity & Mediocre & 70 & $12.61 \%$ \\
\hline & & nominal & 65 & $11.71 \%$ \\
\hline 15 & Presence of platforms & Platforms present & 120 & $21.62 \%$ \\
\hline & inside the pond & Platforms absent & 435 & $78.37 \%$ \\
\hline 16 & Overall condition of & Good & 45 & $8 \%$ \\
\hline & quality of water & Nominal & 60 & $12 \%$ \\
\hline & & Extremely poor & 450 & $80 \%$ \\
\hline
\end{tabular}


This paper attempts to focus attention on the ongoing, although undeliberate, destruction and elimination of rural wetlands in Haryana state in India. On one hand, we have a convention like Ramsar Convention (1971) and on the other hand, we have a situation where each and every wetland is facing grave multiple threats (Plate-1). We should have to call "Spade-a-Spade". We should ensure similarity between what we "say" and what we "do". Ramsar Convention should not be there for official Jargons. Instead it should peep into the bad scenario of bad wetlands, place by place, countryside and continent wise. The combined effect of our inadvertent bad actions on our wetland will one day turn Wetlands as possession of good museums. The society at large be awakened about the urgent need to save wetlands. Schools, Colleges and Universities syllabi should include wetland in Syllabus highlight their significance, importance, utility in the overall functioning of human society.

\section{CONCLUSION}

It is recommended that Panchayats be issued express Orders to harness efforts to rehabilitate the over deteriorated ponds in Haryana. The National Service Scheme (NSS) should singularly focus attention on village ponds to retrieve them as far as possible. Mahatama Ganghi National Rural Employment Gramin Rojgar Yojna (MNREGA) should target redressal of village ponds through its huge financial money. Indian Government must cooperate with concerned international concerned quarters (Ramsar Convention+ Wetland International) to evoke response and help which is lying on our door stays only considering their concern for rehabilitation of wetlands at global level.

\section{ACKNOWLEDGMENTS}

The authors are thankful to their respective better half for granting allowance of time for field surveys. The authors are grateful to authorities of Kurukshetra University, including chairman department of zoology for inspiring and extending cooperation.

\section{REFERENCES}

1. Gupta R C and T K Kaushik (2010A) Determination of the domain of spectrum concerning diversity of endangered winter visitor wetland birds in Haryana. J Expt. Zool. India. 13 (2):349-354.
2. Gupta RC, TK Kaushik, S Kumar ( 2010A) Evaluation of the extent of wetland birds in district Kaithal, Haryana, India. J Appl \& Nat Sci. 2(1):77-84.

3. Gupta, RC, T K Kaushik, S Kumar (2010B) An account concerning arrival and departure time of few selected winter migratory birds in Haryana rural ponds. Environment conservation Journal. 11(1\&2):1-9, 2010

4. Gupta RC, M Parasher, T K Kaushik (2011) An Enquiry into the Avian Biodiversity of Bhindawas Bird Sanctuary in Jhajjar District in Haryana State in India. J Exp Zool. India. 14(2):457-465.

5. Gupta RC, T K Kaushik (2010B) Computation of wetland birds in rural areas of Kurukshetra, Haryana, India. J Natcon. 22(1):1-11.

6. Gupta RC, TK Kaushik (2010C) On the causative factors responsible for the pathetic plight of Yellow wattled Lapwing in Kurukshetra suburbs. J Natcon. 22(2):181-187.

7. Gupta RC, T K Kaushik (2010D) Determination of spectrum of winter migratory birds in Yamunanagar district in Haryana, India. Environment conservation Journal. 11(3):37-43.

8. Gupta RC, T K Kaushik (2010E) Understanding Rural Ponds' Migratory Avian Diversity in Panchkula District in Haryana, India. J Adv Zool. 31(2):117-123.

9. Gupta RC, TK Kaushik (2011A) On the fast depleting trends of Cormorants in Kurukshetra wetlands in the last twenty five years. J Expt Zool India. 14(1):81-85.

10. Gupta RC, TK Kaushik (2011B) On the fundamentatals of natural history and present threats to Red-wattled Lapwing in Kurukshetra environs. J Appl \& Nat Sci. 3(1):62-67.

11. Gupta RC, M Parasher, TK Kaushik (2010) Analysis of Avifauna of Chilchilla Bird Sanctuary in Haryana, India. J Adv Zool. 31(1):35-44.

12. Gupta RC, TK Kaushik, S Kumar (2009) Analysis of winter migratory Wetland Birds in Karnal district in Haryana. J Adv Zool. 30(2):104-117.

13. Gupta RC, M Bajaj (1997) Preliminary investigations into the migratory birds of Braham Sarower at Kurukshetra. Jeevanti. 15:29-41

14. Gupta RC, M Bajaj (1998) Preliminary observations on winter avifauna of a perennial sewer wetland body of Kurukshetra. Jeevanti. 16:46-57.

15. Gupta RC, M Bajaj (1999) An analysis of Ecological and behavioral patterns of migratory Shoveller (Anas clypeata) (Linnaeus) in certain wetlands of Haryana. Jeevanti. 17:27-35.

16. Gupta RC, M Bajaj (2000) Preliminary observation on a rare lapwing species, whitetailed, (Vanellus leucurus) (Lichtenstein). J NATCON. 12(2):197-203. 